\title{
Pengembangan Teknologi Game Indonesia untuk Game 2D “HEROES OF INDONESIA” Menggunakan Unity 2D Engine Berbasis Mobile
}

\author{
${ }^{1}$ Fazriyanor Kaurie, ${ }^{2}$ Agung Purwanto, ${ }^{3}$ Minarni \\ 1,2,3 Program Studi Sistem Informasi, Fakultas Ilmu Komputer, Universitas Darwan Ali
}

\author{
Alamat Surat \\ Email: fazriyanorkaurie@gmail.com*
}

Article History:

Received: 08-Nopember-2020; Received in Revised: 10-Nopember-2020; Accepted: 14-Nopember-2020

\begin{abstract}
ABSTRAK
Pengembangan Teknologi Game Indonesia Untuk Game 2D "Heroes Of Indonesia" Menggunakan Unity 2D Engine Berbasis Mobile merupakan game dengan genre Action-Adventure, yang berguna sebagai hiburan serta sarana edukasi pengenalan sejarah kemerdekaan Indonesia kepada para pemainnya yang dirancang untuk smartphone berbasis Android. Penelitian ini dilakukan dengan cara membandingkan game sejenis. Untuk metode perancangannya dimulai dari tahap Analisis Data, Desain Sistem, Pembuatan Program, Pengujian, Implementasi, dan Evaluasi. Simpulan dari skripsi ini adalah perpaduan antara rintangan dan edukasi berupa kuis dalam game "Heroes Of Indonesia" merupakan media yang efektif dan menarik untuk mengenalkan sejarah apa saja yang terjadi dalam tercapainya kemerdekaan Indonesia. Tanggapan dari responden juga terhibur dengan memainkan game "Heroes Of Indonesia".
\end{abstract}

Kata kunci: Action-Adventure; Game; Sejarah Kemerdekaan Indonesia; Unity 2D

ABSTRACT

Development of Indonesian Game Technology for 2D Games "Heroes Of Indonesia" Using a Mobilebased Unity 2D Engine is a game with the Action-Adventure genre, which is useful as an entertainment and educational tool to introduce the history of Indonesian independence to its players designed for Android-based smartphones. This research was conducted by comparing similar games. The design method starts from the data analysis stage, system design, program development, testing, implementation, and evaluation. This thesis's conclusion is a combination of obstacles and education in the form of a quiz in the game "Heroes Of Indonesia," a fair and exciting medium to introduce Indonesian independence history. Responses from respondents were also entertained by playing the game "Heroes Of Indonesia."

Keywords: Action-Adventure; Games; History of Indonesian Independence; Unity $2 D$

\section{PENDAHULUAN}

Republik Indonesia atau yang lebih umum dikenal Indonesia adalah negara yang terletak di Asia Tenggara yang dilalui oleh garis Khatulistiwa dan berada di antara benua Asia dan benua Australia serta samudera Hindia dan Pasifik. Jumlah pulau yang dimiliki oleh Indonesia adalah sebanyak 17.508 pulau dengan keseluruhan luas wilayahnya adalah sebesar $1,904,569 \mathrm{~km}^{2}$. Namun sayang, sejarah akan kemerdekaan negara Indonesia sekarang kurang diminati oleh generasi muda anak bangsa, hadirnya internet dan smartphone sebetulnya bisa digunakan untuk mencari tahu 
lebih dalam tentang sejarah kemerdekaan Indonesia seperti Perang Diponegoro, Bandung Lautan Api, Peristiwa 10 November dan Pasukan Payung RI Kalimantan.

Keberadaan dan peranan teknologi informasi di segala sektor kehidupan tanpa sadar telah membawa dunia memasuki era baru globalisasi lebih cepat dari yang dibayangkan semula. Dampaknya tidak hanya berpengaruh pada sisi makro ekonomi dan politik masing-masing negara yang dipengaruhinya, tetapi lebih jauh telah merasuki aspek-aspek sosial budaya manusia. Smartphone merupakan salah satu dari perkembangan teknologi yang berfungsi tidak hanya untuk alat komunikasi saja, tetapi bisa digunakan untuk mengakses internet, berfoto, mengirim data, bahkan sebagai sarana hiburan seperti bermain game. Seiring peningkatan kebutuhan smartphone, aplikasi terhadap ponsel pada umumnya dan juga smartphone khususnya kian berkembang.

Mengikuti perkembangan teknologi yang ada, permainan anak-anak dan tanpa terkecuali remaja sebagian besar mengarah pada game. Education game adalah permainan yang bersifat mendidik. Permainan edukatif adalah suatu kegiatan yang sangat menyenangkan dan dapat merupakan cara atau alat pendidikan yang bersifat mendidik. Game ini merupakan sebuah permainan yang didalamnya berisi pertanyaan seputar ilmu dan pengetahuan yang bertujuan untuk menambah wawasan kepada para pemain. Game sendiri memiliki berbagai macam genre, mulai dari RPG, FPS, $T P S$, arcade, puzzle, strategi, simulasi, olahraga, dan sebagainya. Hasil penelitian menunjukkan bahwa tingkat kelayakan education game sebagai media pembelajaran berbasis RPG (Role Playing Game) pada aspek validitas dinyatakan sangat layak dengan hasil rating sebesar $85 \%$. (Maharani et al., 2016)

\section{METODE}

Dalam penyusunan laporan, penulis menggunakan beberapa metode dan berpegang pada teknik-teknik sebagai berikut:

\subsection{Pengumpulan Data}

Tahap pengumpulan data dengan cara mengumpulkan dan mempelajari referensi-referensi yang berkaitan dengan judul penelitian.

a. Studi Pustaka

Peneliti mengumpulkan data dengan cara mencari referensi buku tentang penelitian terdahulu yang masih berkaitan dengan penelitian yang dilakukan sekarang.

b. Observasi

Mengumpulkan data dengan cara memainkan sekaligus mengamati langsung permainan sejenis yang sudah ada.

c. Wawancara

Peneliti mengumpulkan data dengan cara melakukan wawancara terhadap para gamers, terutama gamers yang memainkan permainan sejenis.

\subsection{Pengembangan Sistem}

a. Analisis Data

Dalam suatu penelitian sangat diperlukan suatu analisis data yang berguna untuk memberikan jawaban atas permasalahan yang sedang di teliti. Analisis data itu sendiri adalah proses mengatur urutan data, mengorganisasikan dalam suatu pola, kategori dan satuan uraian dasar.

b. Desain Sistem

Desain sistem adalah merancang atau membuat sistem baru yang di harapkan mampu mengatasi masalah sistem lama, atau dapat juga didefinisikan sebagai penggambaran serta pendefinisian dari suatu masalah, perencanaan dan pembuatan rancangan atau pengaturan dari beberapa elemen yang terpisah dari satu kesatuan yang utuh.

c. Pembuatan Program

Pembuatan program bisa juga disebut sebagai tahap pengkodean yaitu tahap penerjemahan data atau pemecahan masalah yang telah di rancang ke dalam bahasa pemrograman tertentu. 

d. Pengujian
Pengujian atau tahap uji coba adalah tahap pengujian terhadap aplikasi yang dibangun.
e. Implementasi
Implementasi adalah tahapan terakhir dari penelitian ini yaitu satu tahapan dimana aplikasi sudah selesai dan siap untuk diterapkan atau digunakan.

\section{LANDASAN TEORI}

\subsection{Indonesia}

Indonesia adalah negara kepulauan terbesar di dunia yang terletak di Asia Tenggara. Jumlah pulau yang dimiliki oleh Indonesia adalah sebanyak 17.508 pulau dengan keseluruhan luas wilayahnya adalah sebesar 1,904,569 km2. Pulau-pulau utama Indonesia adalah Pulau Sumatera, Pulau Kalimantan, Pulau Jawa, Pulau Sulawesi dan Pulau Papua. Secara astronomis, Indonesia yang berada diantara Benua Asia dan Benua Australia ini terletak di antara $6^{\circ} \mathrm{LU}-11^{\circ} 08^{\prime} \mathrm{LS}$ dan dari $95^{\circ} \mathrm{BT}-141^{\circ} 45^{\prime} \mathrm{BT}$. Indonesia berbatasan darat dengan negara Papua Nugini di Pulau Papua, Malaysia di pulau Kalimantan dan Timor Leste di Pulau Timor. Sedangkan Negara yang berbatasan laut dengan Indonesia adalah Singapura, Filipina, Australia dan India (Kepulauan Andaman dan Nikobar). (Archive, 2019)

\subsection{Game}

Game adalah interaksi antarmuka dengan pengguna untuk menghasilkan umpan balik secara visual pada perangkat video. Kata video dalam Video game tradisional dinyatakan sebagai perangkat tampilan raster. Namun seiring semakin seringnya dipergunakan istilah "Video game", saat ini istilah permainan video dapat digunakan sebagai penyebutan dalam permainan pada perangkat layar apa pun. Sistem perangkat elektronik yang dipergunakan sebagai tempat bermain Video game disebut dengan istilah platform, contoh ini adalah komputer pribadi dan konsol permainan video. Platform ini dari tingkatan yang paling besar seperti komputer mainframe hingga yang paling kecil yaitu perangkat mobile. Video game khusus seperti game arcade, sementara sebelumnya umum, telah berangsur-angsur menurun digunakan. (Jailani \& Purwanto, 2019)

\subsection{Action-Adventure}

Action games berfokus terhadap kemampuan fisik pemain serta koordinasi yang baik antara tangan dan mata. Untuk action games yang sengat cepat yang mengandalkan reflek, pemain tidak memiliki banyak waktu untuk menerapkan strategi atau merencanakan sesuatu. Biasanya dalam action games, kecepatan dalam bereaksi sangatlah dibutuhkan dibandingkan strategi, walau terkadang membutuhkan strategi namun yang paling menonjol adalah kemampuan fisik serta koordinasi tangan dan mata. Beberapa sub-genre dari action game yaitu shooters, fighting games, fast puzzle games, action-adventure, music-dance-rhythm games. (Adams, 2013)

Adventure games berbeda dengan game yang lain. Adventure game merupakan cerita interaktif yang dimainkan oleh tokoh protagonis yaitu si pemain sendiri. Elemen atau essensi dasar dari game ini adalah alur cerita dan eksplorasi. Adventure game biasanya memiliki sistem ekonomi tersendiri dan memiliki action yang lebih (problem solving and combat) dalam menjalani alur cerita yang telah disusun oleh sistem. (Adams, 2013)

\subsection{Unity 2D}

Bisa dibilang Unity ini mendukung untuk pembuatan game berbasis 2 dimensi, maupun 3 dimensi. Selain itu, gambar obyek pendukung yang disediakan pun cukup beragam mulai dari 2 dimensi yang paling sederhana, hingga 3 dimensi yang rumit. Selain itu, Unity pun mampu mengambil gambar dari perangkat lunak seperti Autodesk 3DS Max, Autodesk Maya, Softimage, Blender, Modo, Zbrush, Cinema 4D, Cheetah 3D, Adobe Photoshop, Adoble Fireworks, dan Allegorithmic Substance. (Jurnal, 2014) 


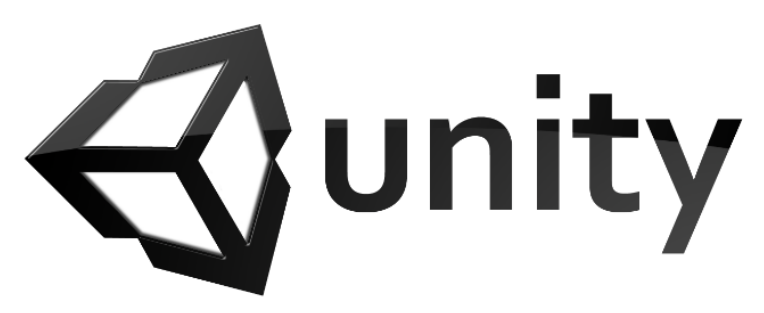

Gambar 1. Logo Unity

Game engine ini pun mendukung beberapa pengembangan aplikasi seperti C\#, UnityScript (berbentuk JavaScript), dan BooScript yang dapat terintegrasi dengan Python. Namun dari ketiga

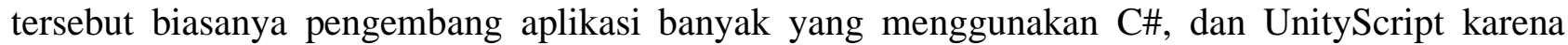
keduanya lebih familiar. (Jurnal, 2014)

\section{HASIL DAN PEMBAHASAN}

Pada tahap ini seluruh rancangan yang sudah dihasilkan, diterjemahkan dengan mengunakan bahasa pem-rograman sehingga menghasilkan sebuah sistem yang diinginkan. Dalam implementasi game pada penelitian ini dilakukan dengan meng-install file .apk yang ada ke smartphone. Pengujian dilakukan dengan mengunakan smartphone dengan sistem operasi Android yang kemudian akan tampil interface halaman utama.

\subsection{Screenshoot Layar Permainan}

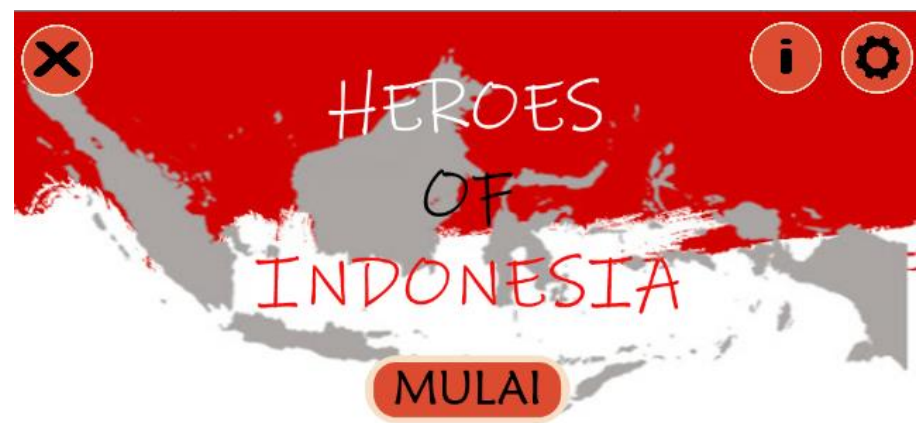

Gambar 2. Screenshot Halaman Utama

Ketika layar halaman utama muncul, pemain dapat memilih tombol Mulai, Pengaturan, Informasi dan Keluar.

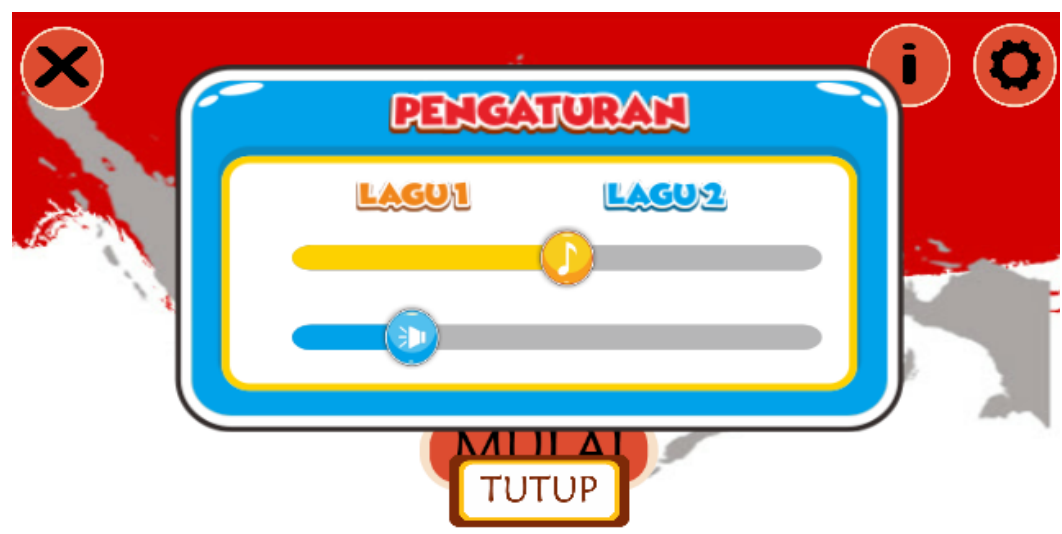

Gambar 3. Screenshot Layar Pengaturan 
Pada halaman pengaturan, pemain dapat mengatur tingkat volume dari musik dan sound yang ada pada game, dengan cara menggeser silinder kearah kanan untuk membesarkan volume dan kearah kiri untuk mengecilkan volume. Selain itu pemain juga dapat mengganti lagu yang akan dimainkan didalam game, yaitu dengan cara menekan tombol "Lagu 1" dan "Lagu 2".

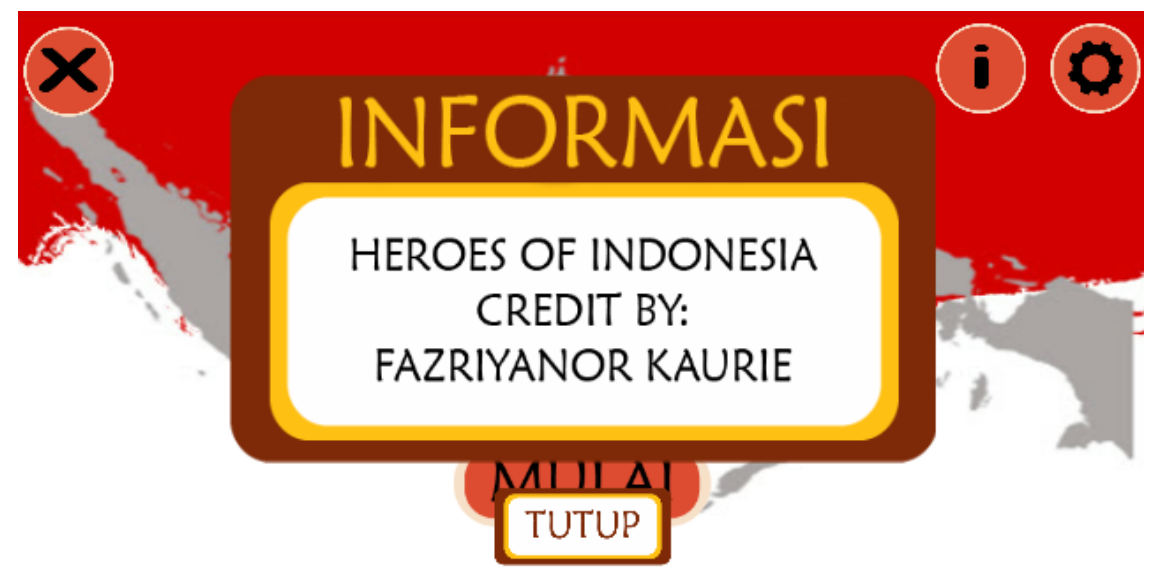

Gambar 4. Screenshot Layar Informasi

Pada halaman informasi, pemain akan mendapatkan informasi tentang pembuat game.

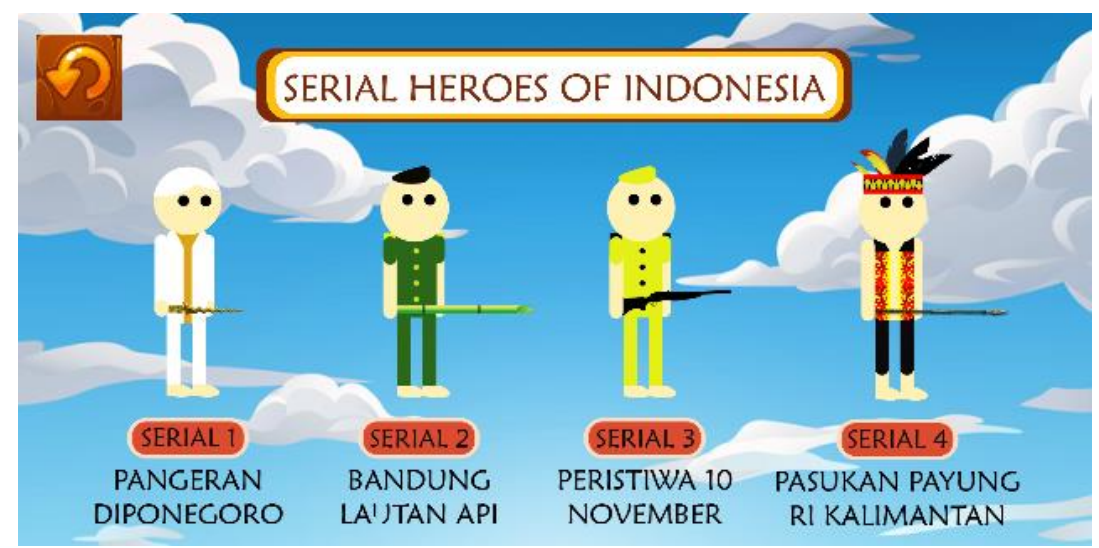

Gambar 5. Screenshot Pilih Serial

Ketika pemain menekan tombol mulai pada layar halaman utama, maka pemain akan dialihkan ke layar pilih Serial. Pada halaman ini pemain dapat memilih Serial mana yang akan dimainkan, yang mana dari setiap serial memiliki cerita sejarahnya sendiri serta tingkat kesulitan yang berbeda-beda.

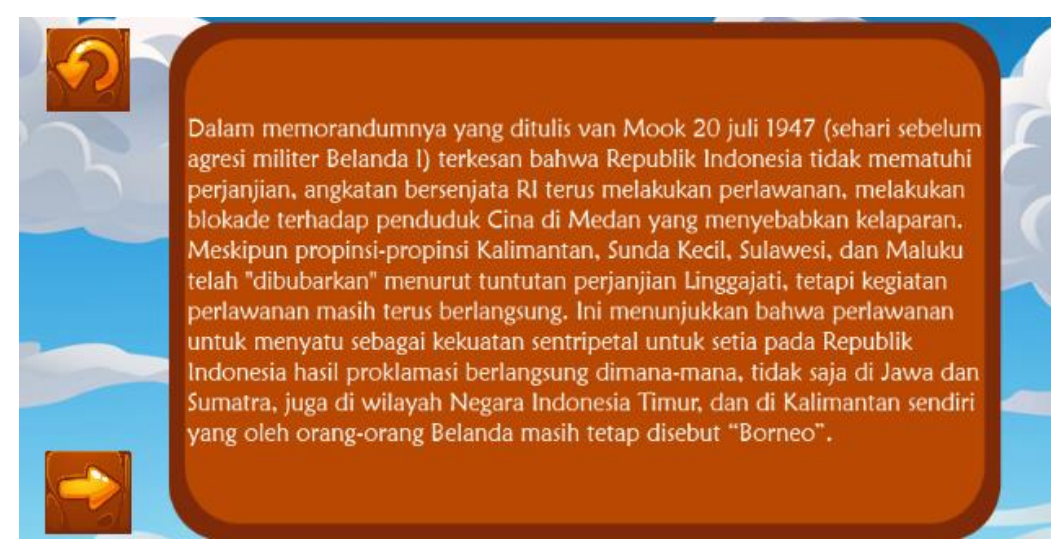

Gambar 6. Screenshot Storytelling Serial 
Setelah pemain memilih salah satu serial yang ada di halaman pilih serial, pemain akan diarahkan ke halaman storytelling serial yang merupakan potongan dari beberapa bagian cerita sejarah yang terjadi pada masa tersebut sebelum memasuki game.

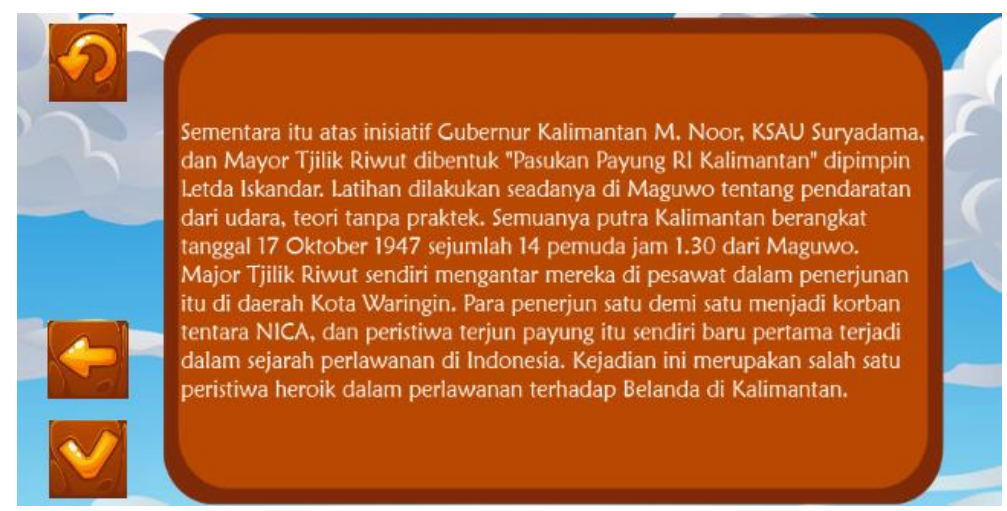

Gambar 7. Screenshot Storytelling Serial

Cerita sejarah yang sudah dipilih pemain dari serial sebelumnya merupakan informasi yang akan digunakan untuk menjawab kuis didalam game yang akan dimainkan.

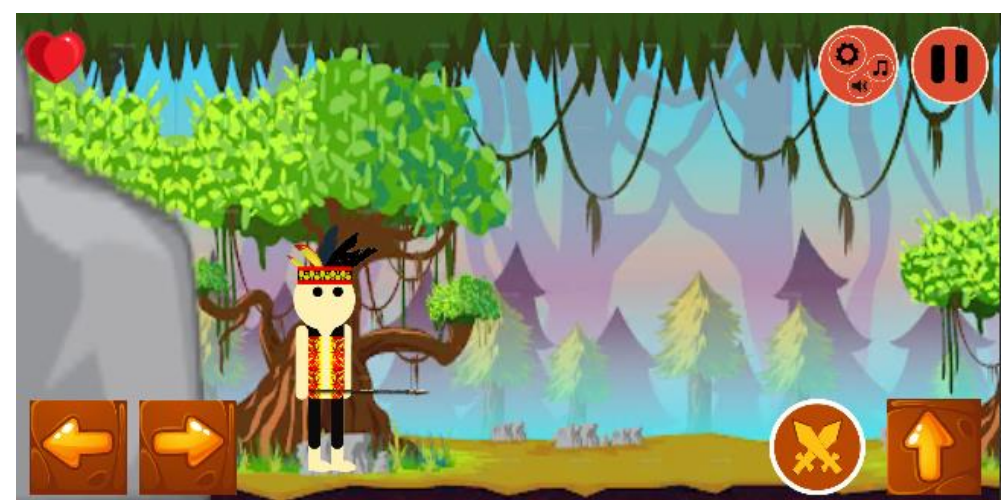

Gambar 8. Screenshot Memulai Permainan

Pada saat pertama kali memulai permainan, karakter akan muncul dengan posisi berdiri tegak. Pada layar tersebut terdapat beberapa tombol untuk mengaktifkan aksi dari karakter tersebut, mulai dari tombol navigasi kearah kanan, navigasi kearah kiri, navigasi untuk melompat, tombol untuk menyerang, tombol pengaturan music dan sound, dan tombol jeda.

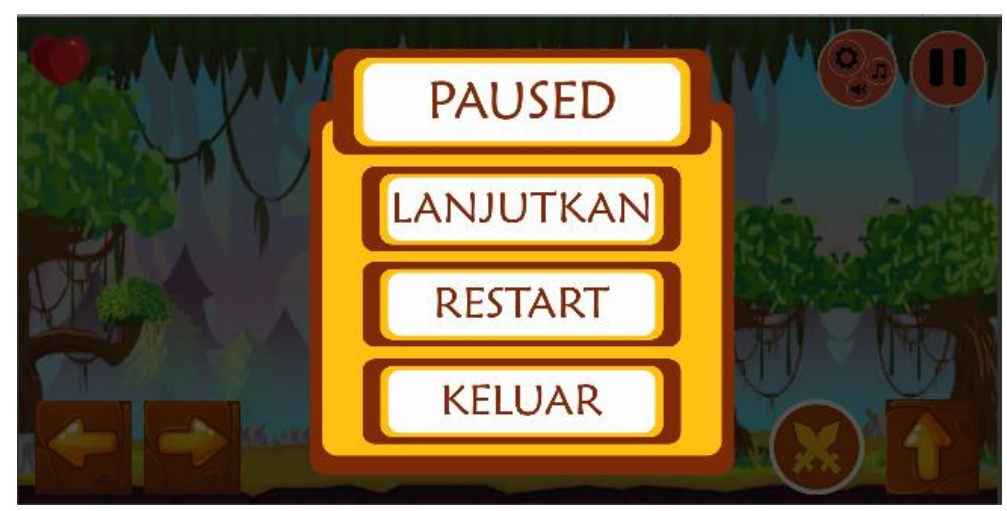

Gambar 9. Screenshot Layar Jeda

Pada pemain menekan tombol jeda, sistem secara otomatis akan mengehentikan game dan menampilkan halaman jeda. Pada halaman jeda, pemain dapat melanjutkan game yang dimainkan 
dengan cara menekan tombol "Lanjutkan", mengulang game dengan cara menekan tombol "Restart", dan Kembali ke halaman utama dengan cara menekan tombol "Keluar".

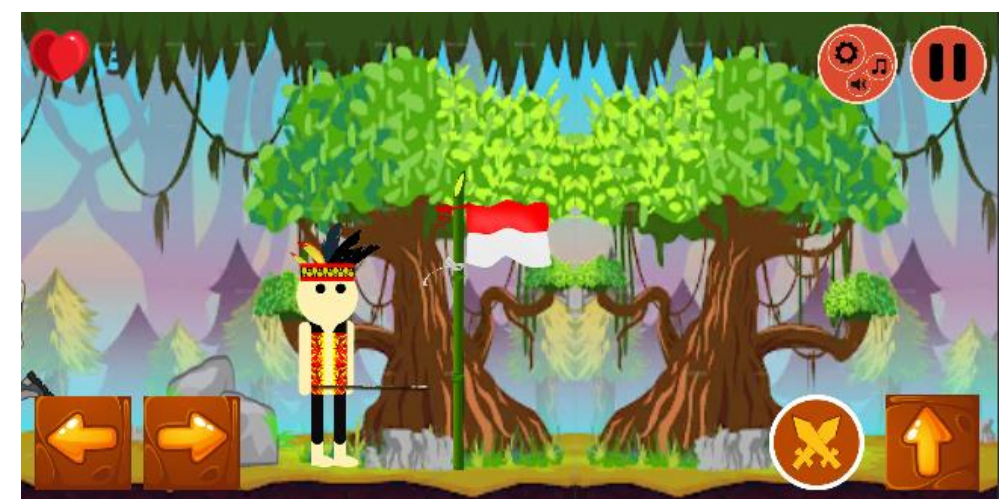

Gambar 10. Screenshot Layar Bendera

Untuk menyelesaikan serial yang dimainkan, pemain harus mengarahkan karakter untuk mencapai bendera merah putih yang ada didalam game. Setelah karakter mencapai bendera merah putih, pemain akan diarahkan ke halaman kuis dari serial yang sudah dipilih.

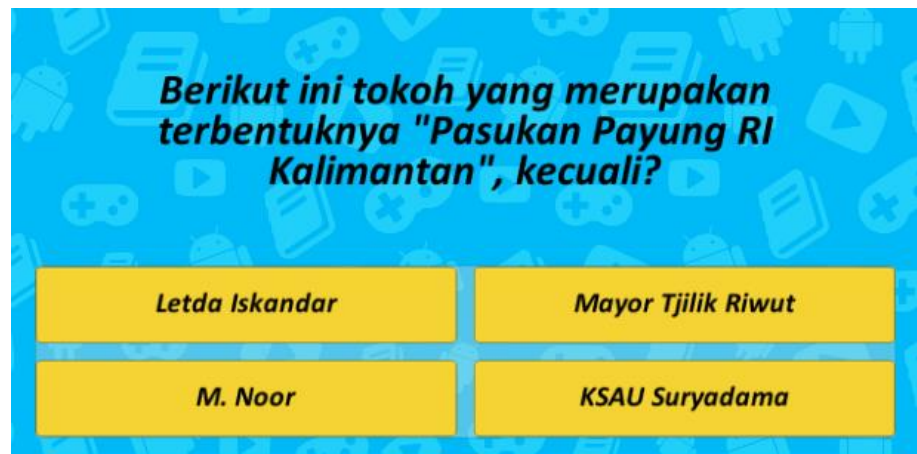

Gambar 11. Screenshot Layar Kuis

Pada halaman ini pemain akan diberikan petanyaan dalam bentuk pilihan ganda dengan 5 macam jenis pertanyaan yang berbeda. Pertanyaan ini diambil dari storytelling serial yang sebelumnya sudah ditampilkan sistem kepada pemain sebelum memasuki game. Jika pemain salah menjawab pertanyaan yang ada pada halaman kuis, pemain akan diarahkan kembali kedalam serial game sebelumnya. Jika pemain benar menjawab pertanyaan yang ada pada halaman kuis, pemain akan diarahkan ke halaman Pilih Serial, yang mana pemain bisa langsung memilih serial mana yang akan dimainkan selanjutnya.

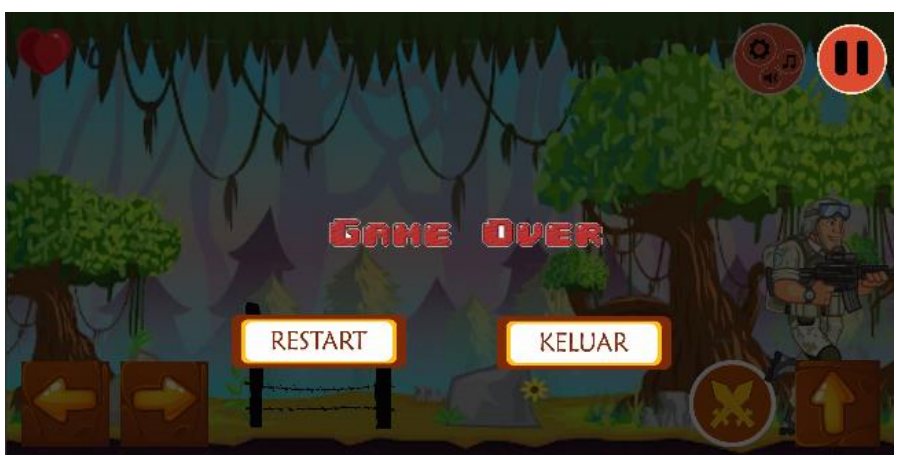

Gambar 12. Screenshot Layar Halaman Saat Karakter Kalah

Jika karakter kehabisan nyawa/life sebelum mencapai bendera merah putih, maka akan tampil halaman saat karakter kalah. Pemain dapat memilih 2 opsi pada halaman ini, yaitu "Restart" untuk 
mengulang dari awal serial game yang dimainkan, dan "Keluar" yang mana pemain akan langsung diarahkan ke halaman utama permainan.

\subsection{Pengujian Sistem}

Di bawah ini akan dilakukan pengujian untuk game "Heroes Of Indonesia". Pengujian ini pada aplikasi ini dapat dilihat pada table dibawah ini:

Tabel 1. Hasil Pengujian Terhadap Halaman Utama Permainan

\begin{tabular}{|c|c|c|c|c|}
\hline \multicolumn{5}{|c|}{ Halaman Utama Pemainan } \\
\hline No & Masukan & Keluaran & Hasil & Kesimpulan \\
\hline 1 & $\begin{array}{l}\text { Pemain menekan } \\
\text { tombol mulai }\end{array}$ & $\begin{array}{l}\text { Masuk ke } \\
\text { halaman pilih } \\
\text { serial }\end{array}$ & $\begin{array}{l}\text { Pemain dapat melihat serial yang } \\
\text { ingin dimainkan dan memilih salah } \\
\text { satu dari serial tersebut }\end{array}$ & Valid \\
\hline 2 & $\begin{array}{l}\text { Pemain menekan } \\
\text { tombol informasi }\end{array}$ & $\begin{array}{l}\text { Sistem akan } \\
\text { menampilkan } \\
\text { halaman } \\
\text { informasi }\end{array}$ & $\begin{array}{l}\text { Pemain dapat melihat infomasi } \\
\text { pembuat game }\end{array}$ & Valid \\
\hline 3 & $\begin{array}{l}\text { Pemain menekan } \\
\text { tombol } \\
\text { pengaturan }\end{array}$ & $\begin{array}{l}\text { Sistem akan } \\
\text { menampilkan } \\
\text { halaman } \\
\text { pengaturan musik } \\
\text { dan sound }\end{array}$ & $\begin{array}{l}\text { Pemain dapat mengganti lagu yang } \\
\text { dimainkan saat game berjalan, } \\
\text { mengatur tingkat volume musik } \\
\text { dan sound }\end{array}$ & Valid \\
\hline 4 & $\begin{array}{l}\text { Pemain menekan } \\
\text { tombol keluar }\end{array}$ & $\begin{array}{l}\text { Sistem akan } \\
\text { mengakhiri game }\end{array}$ & Pemain akan keluar dari game & Valid \\
\hline
\end{tabular}

Pada tabel 1 dapat dilihat bahwa dari 4 macam jenis pengujian, untuk masing-masing tombol sudah berfungsi dengan baik. Pada tombol mulai, sistem akan mengarahkan pemain ke halaman pilih serial, yang mana pada halaman ini pemain dapat memilih salah satu dari berbagai serial yang ada. Kemudian pada tombol informasi, pemain dapat mengetahui informasi tentang pembuat game. Untuk tombol pengaturan, pemain dapat mengganti lagu dan mengatur tingkat volume pada saat game dimainkan. Adapun tombol keluar, berfungsi jika pemain ingin keluar atau mengakhiri game.

\section{Tabel 2. Hasil Pengujian Terhadap Halaman Pilih Serial}

\begin{tabular}{|l|l|l|l|l|}
\hline \multicolumn{3}{|l|}{ Halaman Pilih Serial } & \multicolumn{1}{|c|}{ Kasukan } \\
\hline No & $\begin{array}{l}\text { Meluaran } \\
\text { salah satu dari } \\
\text { beberapa serial } \\
\text { yang tersedia }\end{array}$ & $\begin{array}{l}\text { Sistem akan } \\
\text { menampilkan } \\
\text { storytelling dari } \\
\text { serial yang dipilih }\end{array}$ & $\begin{array}{l}\text { Pemain dapat membaca potongan } \\
\text { cerita sejarah dari serial yang } \\
\text { dipilih, yang mana potongan cerita } \\
\text { tersebut memiliki hubungan dengan } \\
\text { game yang akan dimainkan. Selain } \\
\text { itu pemain juga mendapatkan } \\
\text { informasi berupa edukasi sejarah } \\
\text { dari serial yang sudah dipilih }\end{array}$ & Valid \\
\hline 2 & $\begin{array}{l}\text { Pemain menekan } \\
\text { tombol arah kiri } \\
\text { atau kanan }\end{array}$ & $\begin{array}{l}\text { Sistem akan } \\
\text { menampilkan } \\
\text { storytelling } \\
\text { berdasarkan } \\
\text { tombol yang } \\
\text { ditekan pemain }\end{array}$ & $\begin{array}{l}\text { Pemain dapat membaca ulang atau } \\
\text { melanjutkan potongan cerita } \\
\text { sejarah dari serial yang dipilih }\end{array}$ & Valid \\
\hline
\end{tabular}




\begin{tabular}{|l|l|l|l|l|}
\hline 3 & $\begin{array}{l}\text { Pemain menekan } \\
\text { tombol tanda } \\
\text { centang atau } \\
\text { ceklist }\end{array}$ & $\begin{array}{l}\text { Sistem akan } \\
\text { menampilkan } \\
\text { halaman memulai } \\
\text { permainan }\end{array}$ & $\begin{array}{l}\text { Pemain dapat langsung memainkan } \\
\text { game dari serial yang sudah dipilih }\end{array}$ & Valid \\
\hline 4 & $\begin{array}{l}\text { Pemain menekan } \\
\text { tombol kembali }\end{array}$ & $\begin{array}{l}\text { Sistem akan } \\
\text { kembali } \\
\text { menampilkan } \\
\text { halaman utama } \\
\text { permainan }\end{array}$ & $\begin{array}{l}\text { Pemain dapat melakukan aksi yang } \\
\text { ada dihalaman utama permainan }\end{array}$ & Valid \\
\hline
\end{tabular}

Pada tabel 2 dapat dilihat bahwa pengujian untuk halaman pilih serial dapat memberikan informasi serta edukasi kepada pemain dari potongan cerita sejarah masing-masing serial yang ada didalam game. Dengan adanya tombol untuk arah kanan dan kiri yang berfungsi untuk melanjutkan atau kembali ke potongan cerita sebelumnya jika ingin dibaca lagi oleh pengguna.

Tabel 3. Hasil Pengujian Terhadap Halaman Memulai Permainan

\begin{tabular}{|l|l|l|l|l|}
\hline \multicolumn{2}{|l}{ Halaman Memulai Permainan } & \multicolumn{1}{|c|}{ Keluaran } & \multicolumn{1}{c|}{ Hasil } & Kesimpulan \\
\hline No & \multicolumn{1}{|c|}{ Masukan } \\
\hline 1 & $\begin{array}{l}\text { Pemain menekan } \\
\text { tombol arah } \\
\text { kanan, kiri, atas, } \\
\text { dan serang }\end{array}$ & $\begin{array}{l}\text { Sistem akan } \\
\text { menjalankan } \\
\text { fungsi sesuai dari } \\
\text { tombol yang } \\
\text { ditekan pemain }\end{array}$ & $\begin{array}{l}\text { Pemain akan mengendalikan aksi } \\
\text { dari pemain yang ada didalam } \\
\text { game }\end{array}$ & Valid \\
\hline 2 & $\begin{array}{l}\text { Pemain menekan } \\
\text { tombol jeda }\end{array}$ & $\begin{array}{l}\text { Sistem akan } \\
\text { menampilkan } \\
\text { halaman jeda }\end{array}$ & $\begin{array}{l}\text { Pemain dapat melakukan 3 aksi } \\
\text { yaitu lanjutkan untuk melanjutkan } \\
\text { game, restart untuk memulai game } \\
\text { dari awal, dan keluar untuk } \\
\text { kembali ke halaman utama }\end{array}$ & Valid \\
\hline 3 & $\begin{array}{l}\text { Pemain } \\
\text { menyentuh } \\
\text { rintangan di } \\
\text { dalam game }\end{array}$ & $\begin{array}{l}\text { Nyawa/life dari } \\
\text { karakter akan } \\
\text { berkurang, dan } \\
\text { posisi karakter } \\
\text { akan kembali ke } \\
\text { posisi awal game }\end{array}$ & $\begin{array}{l}\text { Jika karakter menyentuh rintangan, } \\
\text { maka nyawa/life karakter akan } \\
\text { berkurang, dan pemain harus } \\
\text { melewatinya untuk menyelesaikan } \\
\text { game }\end{array}$ & Valid \\
\hline 4 & $\begin{array}{l}\text { Pemain } \\
\text { mengalahkan } \\
\text { musuh di dalam } \\
\text { game }\end{array}$ & $\begin{array}{l}\text { Musuh akan } \\
\text { menghilang dari } \\
\text { game, namun } \\
\text { akan nada efek } \\
\text { yang muncul saat } \\
\text { musuh dikalahkan }\end{array}$ & $\begin{array}{l}\text { Jika pemain berhasil mengalahkan } \\
\text { musuh yang ada di dalam game, } \\
\text { maka akan memudahkan pemain } \\
\text { untuk menyelesaikan game }\end{array}$ & Valid \\
\hline 5 & $\begin{array}{l}\text { Karakter yang } \\
\text { ada di dalam } \\
\text { game kehabisan } \\
\text { nyawa/life }\end{array}$ & $\begin{array}{l}\text { Sistem akan } \\
\text { menampilkan } \\
\text { halaman saat } \\
\text { karakter kalah }\end{array}$ & $\begin{array}{l}\text { Saat karakter yang dimainkan } \\
\text { pemain di dalam game kehabisan } \\
\text { nyawa/life, maka game akan } \\
\text { berakhir }\end{array}$ & Valid \\
\hline
\end{tabular}

Pada tabel 3 dapat dilihat bahwa pengujian untuk halaman memulai permainan, pemain dapat melakukan aksi dengan semua tombol, mulai dari tombol arah kanan, kiri, lompat, serang, jeda, animasi saat musuh dikalahkan, saat karakter menyentuh rintangan, serta saat karakter kalah karena kehabisan nyawa/life. 
Tabel 4. Hasil Pengujian Terhadap Halaman Kuis Dalam Game

\begin{tabular}{|c|c|c|c|c|}
\hline \multicolumn{5}{|c|}{ Halaman Kuis Dalam Game } \\
\hline No & Masukan & Keluaran & Hasil & Kesimpulan \\
\hline 1 & $\begin{array}{l}\text { Jawaban yang } \\
\text { dipilih pemain } \\
\text { salah }\end{array}$ & $\begin{array}{l}\text { Sistem akan } \\
\text { mengulang serial } \\
\text { game dari awal }\end{array}$ & $\begin{array}{l}\text { Jika pemain salah menjawab soal } \\
\text { kuis yang diberikan, pemain akan } \\
\text { mengulangi serial game dari awal } \\
\text { dan harus menyelesaikan ulang } \\
\text { serial game tersebut }\end{array}$ & Valid \\
\hline 2 & $\begin{array}{l}\text { Jawaban yang } \\
\text { dipilih pemain } \\
\text { benar }\end{array}$ & $\begin{array}{l}\text { Sistem akan } \\
\text { menampilkan } \\
\text { halaman pilih } \\
\text { serial }\end{array}$ & $\begin{array}{l}\text { Jika soal kuis yang dijawab pemain } \\
\text { benar, maka game serial yang } \\
\text { dimainkan selesai, dan pemain } \\
\text { langsung diarahkan ke halaman } \\
\text { pilih serial untuk memainkan serial } \\
\text { game yang lainnya }\end{array}$ & Valid \\
\hline 3 & $\begin{array}{l}\text { Bermain game } \\
\text { dengan platform } \\
\text { mobile }\end{array}$ & $\begin{array}{l}\text { File dengan } \\
\text { format .apk untuk } \\
\text { implementasi ke } \\
\text { OS Android }\end{array}$ & $\begin{array}{l}\text { Dapat dimainkan pada platform } \\
\text { mobile (Android) }\end{array}$ & Valid \\
\hline
\end{tabular}

Pada tabel 4 dapat dilihat bahwa pengujian untuk game mobile, semua fitur yang ada di dalam game dapat berfungsi dengan baik. Adanya kuis dalam bentuk pilihan ganda/multiple choice yang ada di dalam game, serta ketikan pemain salah menjawab kuis tersebut yang mengharuskan pemain mengulangi kembali serial game dari awal, akan membuat pemain lebih serius lagi ketika membaca potongan cerita sejarah yang ada sebelum memasuki game untuk menjawab kuis yang diberikan. Selain itu, game ini juga sudah dapat dimainkan pada platform mobile (Android).

Tabel 5. Hasil Pengujian Terhadap Nilai Pendidikan

\begin{tabular}{|l|l|l|l|l|}
\hline \multicolumn{2}{|l|}{ NILAI EDUKASI } & \multicolumn{1}{|c|}{ Masukan } & \multicolumn{1}{|c|}{ Keluaran } & \multicolumn{1}{c|}{ Hasil } \\
\hline No & $\begin{array}{l}\text { Asset game berupa } \\
\text { bendera Indonesia } \\
\text { dan pulau-pulau } \\
\text { yang ada di } \\
\text { Indonesia }\end{array}$ & $\begin{array}{l}\text { Objek pada } \\
\text { halaman utama } \\
\text { berupa } \\
\text { background } \\
\text { game }\end{array}$ & $\begin{array}{l}\text { Memberikan nilai pendidikan } \\
\text { bahwa Indonesia memiliki banyak } \\
\text { sekali pulau, baik itu pulau yang } \\
\text { besar sampai pulau yang kecil }\end{array}$ & Valid \\
\hline 2 & $\begin{array}{l}\text { Asset game berupa } \\
\text { topografi kota } \\
\text { yang sedang } \\
\text { terbakar dan dalam } \\
\text { masa perang }\end{array}$ & $\begin{array}{l}\text { Objek pada serial } \\
\text { 2 dengan tema } \\
\text { Bandung Lautan } \\
\text { Api }\end{array}$ & $\begin{array}{l}\text { Memberikan nilai pendidikan } \\
\text { bahwa kondisi perlawanan saat } \\
\text { rakyat Bandung terhadap para } \\
\text { penjajah yaitu dengan cara } \\
\text { membakar kota Bandung agar para } \\
\text { penjajah tidak dapat mengambil } \\
\text { apapun dari kota Bandung }\end{array}$ & Valid \\
\hline 3 & $\begin{array}{l}\text { Asset game berupa } \\
\text { topografi yang } \\
\text { hamper mendekati } \\
\text { topografi pulau } \\
\text { Kalimantan } \\
\text { Tengah }\end{array}$ & $\begin{array}{l}\text { Objek pada serial } \\
\text { 4 dengan tema } \\
\text { Pasukan Payung } \\
\text { RI Kalimantan }\end{array}$ & $\begin{array}{l}\text { Memberikan nilai pendidikan } \\
\text { berupa pengetahuan tentang } \\
\text { topografi pulau Kalimantan } \\
\text { terutama Kalimantan Tengah }\end{array}$ & Valid \\
\hline 4 & $\begin{array}{l}\text { Asset game berupa } \\
\text { pakaian dan hiasan }\end{array}$ & $\begin{array}{l}\text { Objek aksesoris } \\
\text { karakter pada }\end{array}$ & $\begin{array}{l}\text { Memberikan nilai pendidikan } \\
\text { berupa pengetahuan tentang }\end{array}$ & Valid \\
\hline
\end{tabular}




\begin{tabular}{|l|l|l|l|l|}
\hline & $\begin{array}{l}\text { kepala pada } \\
\text { karakter }\end{array}$ & $\begin{array}{l}\text { serial 4 dengan } \\
\text { tema Pasukan } \\
\text { Payung RI } \\
\text { Kalimantan }\end{array}$ & $\begin{array}{l}\text { pakaian adat dan hiasan kepala } \\
\text { khas Kalimantan terutama } \\
\text { Kalimantan Tengah yaitu suku } \\
\text { Dayak }\end{array}$ & \\
\hline 5 & $\begin{array}{l}\text { Asset game berupa } \\
\text { senjata yang } \\
\text { digunakan karakter }\end{array}$ & $\begin{array}{l}\text { Objek pada } \\
\text { masing-masing } \\
\text { serial yang } \\
\text { memiliki masing } \\
\text { senjata yang } \\
\text { berbeda }\end{array}$ & $\begin{array}{l}\text { Memberikan nilai pendidikan } \\
\text { berupa pengetahuan tentang senjata } \\
\text { apa saja yang digunakan rakyat } \\
\text { untuk melalukan perlawanan dari } \\
\text { para penjajah dalam meraih } \\
\text { kemerdekaan Indonesia }\end{array}$ & Valid \\
\hline 6 & $\begin{array}{l}\text { Asset game berupa } \\
\text { backsound } \\
\text { instrument 17 } \\
\text { Agustus 1945, } \\
\text { Bagimu Negeri, } \\
\text { Garuda Pancasila, } \\
\text { halaman utama } \\
\text { permainan dan } \\
\text { pada masing- } \\
\text { masing serial saat } \\
\text { di dalam game }\end{array}$ & $\begin{array}{l}\text { Memberikan nilai pendidikan } \\
\text { berupa pengetahuan tentang lagu- } \\
\text { lagu apa saja yang menjadi lagu } \\
\text { nasional Indonesia untuk } \\
\text { menumbuhkan dan menanamkan } \\
\text { rasa cinta tanah air }\end{array}$ & Valid \\
Bandung, \\
$\begin{array}{l}\text { Indonesia Pusaka, } \\
\text { Maju Tak Gentar, } \\
\text { dan Indonesia } \\
\text { Raya }\end{array}$ & & & \\
\end{tabular}

Pada tabel 5 dapat dilihat bahwa game "Heroes Of Indonesia" dapat memberikan nilai pendidikan tentang sejarah kemerdekaan Indonesia. Nilai-nilai pendidikan tersebut diantaranya background bendera Indonesia yang didalamnya terdapat pulau-pulau yang ada di Indonesia, senjata yang digunakan saat melawan para penjajah, lagu-lagu nasional Indonesia, dan pakaian adat dan hiasan kepala khas Kalimantan Tengah yaitu suku Dayak.

\section{KESIMPULAN}

Berdasarkan program yang sudah dibuat, kesimpulan yang diperoleh dari perancangan aplikasi mobile game Heroes of Indonesia adalah:

1. Aplikasi mobile game Heroes Of Indonesia dengan fitur Action-Adventure ini bersifat sederhana dan mudah sehingga dapat dimainkan oleh semua kalangan baik anak maupun dewasa.

2. Fitur serial, karakter, dan edukasi berupa kuis yang beragam pada game Heroes Of Indonesia memberikan gameplay menarik sehingga disukai semua kalangan.

3. Perpaduan serial, karakter, dan kuis yang beragam dalam tema game Heroes Of Indonesia merupakan media yang menarik dan efektif untuk memberikan edukasi dari beberapa cerita sejarah akan kemerdekaan negara Indonesia kepada pengguna.

\section{DAFTAR PUSTAKA}

Adams, E. (2013). Fundamentals Of Game Design, Third Edition, Ketiga. United States, New Riders, 1(1).

Archive, T. W. F. (2019). Data-data Profil Negara Indonesia ini dikutip dari CIA World Factbook. Central Intelligence Agency, 1(1).

Jailani, R., \& Purwanto, A. (2019). Rancang Bangun Game 2D Dayak Run Bergenre Endles Running Berbasis Android. Inform: Jurnal Ilmiah Bidang Teknologi Informasi Dan Komunikasi, 4(2). 
Jurnal, T. (2014). Unity-Game Engine Tangguh Untuk Berbagai Platform. Tekno Jurnal, 1(1).

Maharani, S., Hatta, H. R., \& Selvyani, F. A. (2016). Game Sejarah Terbentuknya Kota Samarinda Menggunakan Role Playing Game (RPG) Maker VX Ace. Jurnal Infotel, 8(1), 56-63. 